\title{
РОЗВИТОК ПАТРІОТИЗМУ МОЛОДІ ПСИХОЛОГІЧНИМИ ЗАСОБАМИ МЕТОДИКИ “МЕДІАКЛУБ”
}

Патріотизм розглядається як динамічна якість особистості, що зумовлюється зовнішніми чинниками, зокрема особливостями конкретного історичного етапу розвитку суспільства. Медіаграмотність і критичне мислення особистості, які $\epsilon$ психологічним імунітетом особистості проти деструктивних інформаційних впливів та запорукою збереження іiі національної ідентичності в умовах інформаційної війни, визначаються як когнітивні інструментальні якості патріота. Представлено медіапсихологічні ресурси, зокрема методику “Медіаклуб”, за допомогою яких можна розвивати патріотизм молоді і патріотичні якості особистості. Показано, як за рахунок зміни процедури зазначеної методики вдалося розширити іiі можливості. Так, до “традиційного” і “рольового” форматів проведення медіаклубу додано модифікований “інтерпретаційний” підхід візуальної соціології, суть якого полягає в різноманітних підходах до інтерпретації сприйнятого. Крім того, розроблено “ідентифікаційний” варіант проведення медіаклубу, учасники якого ототожнюють себе з героєм фільму, а потім рефлектують власні емоції, почуття, аналізують думки, викликані цим “перевтіленням”. Звертається увага на те, що медіаклуб у форматі “стоп-кадр” як зупинення рухомого зображення дає змогу більш детально проаналізувати попередній фрагмент або ключовий кадр фільму. “Ілюстративний” формат медіаклубу передбачає використання “нарізок” з різних фільмів, які ілюструють сюжети однієї теми. Обстоюється доцільність цього формату для засвоєння певної теми, проведення дискусії.

Ключові слова: патріотизм особистості, нові інструментальні якості патріота, медіапсихологічні засоби, методика медіаклуб, нові формати проведення медіаклубу.

Постановка проблеми. Актуальність розвитку патріотизму молоді, українізації регіонів країни обумовлена не тільки консолідацією нації, реінтеграцією українського суспільства в цілому, а й потребою забезпечення патріотично-виховного процесу новими, ефективними засобами. Проблема патріотичного виховання, яке часто-густо здійснюється за старими, радянськими методичними шаблонами, потребує свого розв'язання саме за допомогою нових/оновлених засобів впливу на особистість. Вважаємо, що ресурси психології загалом і медіапсихології зокрема здатні забезпечити патріотично спрямований виховний процес інноваційним методичним інструментарієм.

Аналіз публікацій, останніх досліджень та виокремлення невирішених частин загальної проблеми. Проблемою засобів виховання патріотизму української молоді як любові до Батьківщини переймалося бага- 
то видатних осіб. Так, у першій половині XX ст. українські мислителі та ідеологи Д. Донцов (1936), 3. Коссак (Стасюк, 2008) і С. Ленкавський (Стасюк, 2009) основним методом патріотичного виховання молоді вважали гартування тіла і духу, тобто розвиток саморегуляції особистості на фізичному і світоглядному рівнях. Педагог Г. Ващенко (1954) пропонував метод спрямованого усвідомлювання дитиною належності до своєї нації, iï історії, культури відповідно до ії віку: від природного, "стихійного”, закладеного з дитинства, до “свідомого” патріотизму. Б. Заклинський (2015) одним із методів формування патріотизму вважав національне самовизначення особистості: “Українець той, хто причисляє себе до українців", тобто це процес свідомої ідентифікації особистості з нацією, незважаючи на iï етнічне походження (с. 7). Видатні педагоги К. Ушинський (1983) і В. Сухомлинський (1990) мали схожі погляди на виховання патріотизму в учнів - через призвичаєння їм любові до рідного краю, природи, народної творчості тощо.

У незалежній Україні питанням патріотизму практично до останнього часу не переймалися ні влада, ні освітяни, ні кіномитці: першим це було невигідно і непотрібно, у других не було мотивації й стимулу, треті, за рідкісним винятком, не мали ані коштів, ані бажання. Анексія Криму, війна на Донбасі стали логічним наслідком цього ганебного явища. Наразі проблема патріотизму як соціокультурного феномена нарешті зрушила 3 місця і стала об'єктом уваги психолого-педагогічних наук. Питання виховання патріотизму, громадянських якостей молоді привертало і привертає увагу таких українських спеціалістів, як I. Бех, П. Вербицька, Н. Волошина, П. Гнатенко, . Жаровська, . Киричук, В. Матящук, Н. Михальченко, В. Павленко, А. Погрібний, Ю. Руденко, Н. Снопко, С. Таглін, К. Чорна, О. Шестопалюк та багато інших. На державному рівні актуальність проблеми виховання патріотизму знайшла своє відображення в таких документах, як Програма українського патріотичного виховання дітей та учнівської молоді (2011), Концепція національнопатріотичного виховання дітей та молоді (2015), Указ Президента України від 13 жовтня 2015 р. "Про Стратегію національно-патріотичного виховання дітей та молоді на 2016-2020 роки”.

Мета статті: представити розширені можливості оновленої методики “Медіаклуб” для розвитку патріотизму молоді.

Виклад основного матеріалу дослідження. Патріотизм за своєю соціокультурною, психологічною природою $є$ динамічним феноменом, який формується, розвивається, зміцнюється або гальмується, тобто постійно трансформується, модифікується під впливом різноманітних зовнішніх чинників. На думку Д. Донцова (1936), у вихованні патріотизму молоді завжди потрібно звертати увагу на те, щцо в цю історичну хвилину $\epsilon$ важливим і затребуваним у суспільстві, щзо є важливим на часі в цілому 
(с. 60). Ми вважаємо за потрібне розвинути, поглибити цю ідею постійного оновлення змісту патріотичного виховання і набуття особистістю актуальних патріотичних якостей, які відповідали б конкретному історичному періоду розвитку українського суспільства.

В умовах розвитку інформаційних технологій, безпрецедентного розмаїття засобів масової інформації та розширення меж кіберпростору, а також ведення тотальних інформаційних воєн вважаємо, що:

1) новою когнітивно-інструментальною якістю патріота має стати особиста медіаграмотність, головним елементом якої є самостійне мислення (Череповська, 2017);

2) на формування патріотичних переконань, цінностей і смислів молоді нині вагомий, як ніколи раніше, але стихійний вплив мають телебачення, інтернет, інші візуальні, аудіовізуальні медіазасоби, тобто кіберпростір у цілому.

Отже, медіаграмотність патріота, як система знань, навичок, умінь, здатна забезпечити його вільне функціонування в новому суспільстві, оптимальну взаємодію з інформаційним простором. Зі свого боку розвинене самостійне, критичне мислення патріотичної молоді підсилює їі імунітет проти деструктивних інформаційних впливів, є запорукою збереження нею своєї національної ідентичності в умовах інформаційної війни.

Водночас зростає роль патріотичного медіаконтенту як способу соціалізації молоді, набуття нею опосередкованого цим контентом патріотичного досвіду. Саме перегляд гарного фільму, участь у його масовому обговоренні в чатах, коментарях, форумах, повторний перегляд стрічки або ії улюблених фрагментів в онлайновому домашньому режимі можуть справити потужний вплив на формування патріотичної особистості. Щоб результатом перегляду стали не тільки емоції, враження, а й усвідомлення нових цінностей і смислів, молодь треба цілеспрямовано навчати психологічно грамотно дивитися медіаконтент і бачити його приховані смисли.

Наша ідея збагаченого розвитку патріотизму полягає в застосуванні медіапсихологічних ресурсів (наприклад, аудіовізуальних технологій i художнього патріотичного медіаконтенту), у засвоєнні молодю таких основних умінь і навичок медіаграмотності, як рефлексія емоцій і почуттів щодо сприйнятого, його критичне осмислення і переосмислення, у розвитку здатності до самостійного оцінювання медіаконтенту, а також умінь віднаходити для себе новий смисловий досвід у переглянутому медіаконтенті (Череповська, 2017).

Оптимізувати процес виховання патріотизму молоді, стимулювати розвиток його нової якості - медіаграмотності - можна за допомогою методики "Медіаклуб". У чому суть цієї методики? По-перше, образносмисловий формат фільму вже сам по собі $є$ неабияким агентом впливу на емоційно-почуттєву сферу особистості. По-друге, аналіз переглянутої 
стрічки формує навички й уміння медіаграмотності: здатність до аналітичної роботи, критичне осмислення сприйнятого, його творче переосмислення тощо. По-третє, спільне обговорення стрічки патріотичного змісту формує не тільки уміння висловлювати свою думку, коректно поводитися під час дискусії, а й свідомий, “розумний” патріотизм, який є передумовою готовності до конструктивних патріотичних дій і вчинків.

Розширення можливостей методики медіаклубу. Зазначена методика "базується на проблемних, евристичних, дискусійних формах навчання, які стимулюють розвиток критичного мислення й творчі здібності аудиторії щодо сприймання, інтерпретації та аналізу медіатекстів. В основу занять покладено принцип інтерактивності - власної активної участі і групової взаємодії, активного обговорення у формі діалогу з дотриманням стилю співробітництва в спілкуванні. Групове обговорення будується на закономірностях динаміки групи із врахуванням специфіки прийняття групового рішення та створення спільного творчого продукту" (Голубєва, Мироненко, \& Стерденко, 2014, с. 5).

Медіаклуб, який можна розглядати певною мірою і як кінотренінг, - це методика, яка для реалізації різних цілей (формування візуальної медіакультури особистості, розвиток медіаграмотності школярів, стимулювання посттравматичного зростання ветеранів війни, формування професійних, менеджерських навичок тощо) широко застосовує кіно, відео та інший візуальний матеріал з медіа, а також використовує медіапсихологічні засоби оптимізації взаємодії людини із сучасною візуальною медіакультурою (Трусь, 2011; Череповська, 2017).

Структура методики проведення медіа клубу. Методикою передбачено процесуальну і результативну частини. Процесуальна частина охоплює підготовчий етап (вступне слово, план роботи) і етап реалізації (перегляд відеоматеріалу, рефлексія емоцій і почуттів щодо сприйнятого, його аналіз, оцінювання і обговорення/дискусія). Результативна частина це етап завершення (підбиття підсумків як переосмислення сприйнятого, фіксація нового - отриманого в ході перегляду, аналізу та обговорення).

За рахунок поглиблення процесуальної частини методики вдалося розширити іiі можливості, зокрема збільшити кількість використовуваних форматів. Розгляньмо останні більш детально.

1. Так званий традиційний формат проведення медіаклубу. Його трискладова структура - вступ, основна частина, завершення - зберігається в інших інноваційних форматах проведення методики (Голубєва, 2014; Трусь, 2011; Череповська, 2017).

2. Рольовий формат медіаклубу передбачає аналізування переглянутого учасниками медіаконтенту з позицій певних ролей. Ролі призначаються/обираються на підготовчому етапі перед переглядом і презентують такі підходи спрямованого сприймання й обговорення фільму: 
“глядацький” - у процесі перегляду забезпечує цілісне, безпосереднє сприйняття медіапродукту, зосередженість на власних переживаннях та емоціях, які стимулюють зацікавленість у його перегляді; акцент робиться на з'ясуванні того, “які думки та почуття виникли”;

“авторський” - реалізує такий тип сприймання медіатексту, який визначає позиції його творця(-ів) і має виявити головну думку, мету твору, а також яким чином вони реалізовувалися; “авторське" сприймання передбачає розкриття таких питань, як: “що хотів сказати автор?”, “у який спосіб автор доніс свою думку до аудиторії?”, “які художні, технічні засоби він застосовував?"; тобто акцент робиться на тому, “як це зроблено”;

“експертний” - реалізує інший тип сприймання медіатексту, який здійснюється 3 позиції експерта-спостерігача або групи спостерігачів; це настановлення глядача на свідомо контрольований, неупереджений, безоцінковий перегляд, що гарантує об'єктивний підхід до аналізу запропонованого медіатексту (у роботі цієї команди глядачів бере участь модератор); акцент робиться на аналізі та критичному, аргументованому оцінюванні медіаконтенту.

У ході спільного обговорення переглянутого фільму спочатку висловлюються “глядачі”, потому - “автори” і насамкінець - “експерти”.

"Глядацька" експертиза медіатексту, який виноситься на розсуд аудиторії, здійснюється у вільному форматі: емоційному, аналітичному, змішаному - не обов'язково послідовно. Відтак “автори” розкривають способи реалізації задуму фільму: коментують внесок режисера, сценариста, оператора, звукорежисера, акторів. "Експертні” оцінки вислуховуються наостанок. "Експерти” аналізують та узагальнюють усе вищесказане, уточнюють, коментують, відповідають на запитання аудиторії.

3. Iнтерпретаційний формат запозичено з аналізу світлин у рамках візуальної соціології (Штомпка, 2007) та модифіковано до потреб перегляду фільмів. Суть формату полягає в застосуванні різних інтерпретаційних підходів сприйнятого, щоб уможливити всебічний аналіз візуального медіатексту загалом і художнього патріотичного медіаконтенту зокрема. Розподіл інтерпретаційних підходів щодо перегляду та аналізу фільму між учасниками здійснюється також на підготовчому етапі.

Перелік інтерпретаційних підходів досить широкий. Серед них гуманістичний, соціальний, психологічний, історичний, “культурологічний”, естетичний, патріотичний та ін. Розгляньмо найбільш поширені.

Гуманістичний підхід дає змогу інтерпретувати медіатекст з позиції його автора(-ів): “Чому режисер зняв саме цей фільм?”, “Чому оператор такий-то епізод зняв у такий спосіб?”, “Що йому в цьому видалося цікавим, вартим уваги?”, “Що хотів сказати своїм фільмом режисер?” тощо. Гуманістичний підхід певним чином перегукується з "авторською" роллю попереднього формату медіаклубу, але смисловий акцент підходу 
на відміну від попереднього формату “як це зроблено?" робиться саме на тому, “що хотіла сказати одна група людей (авторів) іншій (глядачам)?”.

Підхід соиіальної взаємодії передбачає відображення у фільмі проблем соціуму; підхід інтерпретує відображену у фільмі подію як візуалізований аспект реального суспільного життя; аналізує і розкриває різні типи соціальної взаємодії в заданому медіаконтенті: "спілкування індивідуалізоване", “поруч, але не разом”, “велика група, але єдина та згуртована", “дружні групи”, “ворожі групи”, “протистояння/конфлікт” тощо.

Психологічний підхід дає змогу акцентувати увагу на переживаннях героїв, їхніх мотивах, діях, вчинках, подвигах; реконструювати психологічний стан героя або, наприклад, провести паралель між психологічними переживаннями героїв минулих історичних подій і світосприйняттям, переживаннями сучасників у схожих ситуаціях.

Культурологічний підхід допомагає сфокусувати увагу на культурному аспекті медіатексту. Так, культурне тло, архітектура, символіка, одяг, що потрапляють у кадр, можуть розкрити, уточнити, інформаційно збагатити культурний контекст події; культурологічний підхід інтерпретує співвіднесення дії фільму з відображеними в ньому навколишніми предметно-культурними, технічними, політичними, економічними реаліями.

Історичний інтерпретаційний підхід полягає в тому, що будь-які медіатексти, і художні стрічки у тому числі, аналізуються з урахуванням відображених історичних, біографічних подій; висувається гіпотеза значущості впливу минулих подій на перебіг подій сучасності, сучасних подій - на майбутні; з'ясовується питання історичної достовірності сюжету, можливих неточностей, причина цих відхилень (задум автора або ж його некомпетентність).

Естетичний підхід розглядає візуальний медіатекст крізь призму його художності, образної цінності; допомагає розрізняти медіапродукцію за категоріями: “фільм-товар" як зразок масової культури (таких фільмів більшість); “фільм-пропаганда”, що також має “право на життя”, особливо в історичних, воєнно-патріотичних контентах; “фільм-твір” - мистецький твір високого художнього гатунку тощо.

У контексті проблематики патріотичного виховання молоді за допомогою медіаресурсів маємо зазначити, що дидактичний матеріал у медіаформаті художніх фільмів, як правило, має пропагандистський характер. Проте для перегляду важливо добирати такі стрічки, в яких пропаганда є збалансованою - не переважає над змістовим, образним наповненням. Так, переважна більшість передвоєнних, воєнних і повоєнних стрічок радянського кінематографа 30-40-х років минулого століття "хворіла" на пафос і домінування ідеологічної пропаганди. Значно меншою мірою “проступає” пропаганда в перших стрічках незалежної України 
90-х років. Згадаймо фільми режисера Олеся Янчука, зокрема "Нескорений” (2000, Україна-Канада), “Залізна сотня” (2004, Україна) та ін. Прикладом пропорційної, виваженої пропаганди можуть бути художні фільми “Далекий постріл” (режисер - В. Шалига, 2005, Україна), "Кіборги" (режисер - А. Сеїтаблаєв, 2017, Україна), “Американський снайпер” (режисер - К. Іствуд, 2014, США).

Патріотичний інтерпретаційний підхід концентрує увагу на поведінці, висловлюваннях, учинках кіногероїв з позиції їхньої любові до Батьківщини; передбачає виявлення репрезентованих у фільмі складових патріотизму особистості (емоційної, розумної/свідомої, дієвої).

Медіапсихологічний підхід дає змогу визначити різноманітні технології впливу на емоції, свідомість перцепієнтів; уточнити найбільш "ефективні” (візуальні, звукові, музичні) моменти та прийоми, за допомогою яких здійснюються психологічні ефекти впливу на глядача.

Інтерпретаційні підходи в реалізації методики медіаклубу допомагають аналізувати медіапродукт з різних боків, що дає змогу осмислити його більш багатогранно: глибше розкрити суть змісту, усвідомити очевидні і приховані смисли, побачити буденне в незвичному ракурсі.

4. Ідентифікаційний формат медіаклубу передбачає специфічний підхід свідомого “ототожнення” глядача з кіногероєм (не обов' язково головним) і “проживання” ним сюжетної лінії фільму в процесі перегляду. Цей формат ніби схожий із психологічним інтерпретаційним підходом, описаним вище, проте має суттєву відмінність. Якщо психологічний підхід в аналізі фільму здійснюється з позиції зовнішнього спостерігача, то ідентифікаційний передбачає можливість подумки поставити себе на місце кіногероя, “прожити” його життя і зіставити репрезентовану психологічну модель персонажа 3 проявами власних аналогічних переживань у заданому сюжеті. Суть підходу полягає в тому, щоб відчути “зсередини" емоції, мотиви поведінки іншого (кіногероя) i, можливо, подумки щось “змінити” (на кшталт “на його місці я б...”), дещо “запозичити” для себе на майбутне або категорично "не погодитися” з учинком героя (“ніколи в житті так не чинитиму”). Також важливо поділитися/обмінятися своїми враженнями і відчуттям від “зроблених учинків" з іншими учасниками групи. Пропозиція модератора щодо ідентифікації учасників медіаклубу з кіногероями фільму також здійснюється на підготовчому етапі: кожен може обрати будь-якого персонажа або декількох. Під час обговорення цікавим і корисним буде саме обмін враженнями щодо “проживання життя кіногероя” різними глядачами. Такий формат медіаклубу варто проводити 3 учасниками не на перших заняттях, а коли вони вже мають досвід участі в медіаклубі або ж знайомі між собою.

Модератору важливо давати учасникам настановлення на майбутне щодо формування в них ментальної звички - наслідування позитивних рис 
характеру персонажа, який сподобався, його поведінки, вчинків. Крім того, надалі в певних ситуаціях моделювати власну поведінку, взоруючи на улюбленого героя.

Як зазначалося вище, трискладова структура проведення медіаклубу (етапи підготовки, реалізації та завершення) $є$ незмінною для всіх його форматів. Проте в наступних двох форматах - “Стоп-кадр" та "Ілюстрація" - процесуальна частина на етапі реалізації (перегляд й обговорення) має відмінності технічного плану.

5. “Cmon-кадp” - формат медіаклубу, в якому прийом “стоп-кадр” застосовується у двох різних варіантах:

1-й варіант: у процесі перегляду в потрібний момент модератор зупиняє фільм і пропонує учасникам медіаклубу коротко проаналізувати тільки-но сприйнятий і зупинений епізод: він звертає увагу на певні речі, дещо коментує, а також заохочує інших до аналізування сприйнятого; таким чином модератор демонструє учасникам групи, як треба робити аналіз, узагальнення, дає приклад неупередженого ставлення до фільму тощо. Цей формат бажано проводити на перших заняттях для призвичаєння учасників до суті роботи у форматі медіаклубу.

2-й варіант: через різні причини фільм переглядають заздалегідь (у кінотеатрі або в домашніх умовах, наодинці чи з друзями). Робота медіаклубу розпочинається відразу після вступного слова модератора. Обговорення ключових моментів фільму починається з перегляду відповідного фрагмента. Потому модератор фіксує найбільш виразний кадр цього фрагмента як візуальний орієнтир для аналізування. (Для цього треба досконало знати медіатекст, щоб швидко знайти потрібне місце в стрічці і зробити “стоп-кадр"). По суті, переглянутий і зупинений фрагмент виконує роль ілюстрації - візуалізації обговорюваного. Таку версію “стоп-кадру" можна застосовувати як прийом аргументації в інших форматах медіаклубу.

Домашній/попередній перегляд може бути запланованим не лише через значну тривалість художньої стрічки, на спільний перегляд якої бракує часу, а й тоді, коли є потреба саме в розширеному іiі обговоренні підготовленій дискусії.

6. “Ілюстрація”. Цей формат проведення медіаклубу на етапі реалізації найбільше відрізняється від усіх попередніх. Він набуває доцільності тоді, коли необхідно розкрити/засвоїти якусь нову або дослідити конкретну тему. Наприклад, якщо тема заняття або дискусії передбачає 3'ясування таких актуальних і соціально гострих питань сьогодення, якот: “За що боролась Українська повстанська армія?”, “Роль національного прапора для вояків різних армій” тощо. Тому на підготовчому етапі акцент робиться саме на актуальності теми, яка буде обговорюватися. Особливість формату “ілюстрація” полягає в тому, що він не має на меті пере- 
гляд однієї стрічки або їі фрагментів. Навпаки, модератор згідно з планом роботи на кожне окреме питання теми почергово демонструє заздалегідь заготовлені “нарізки” (з кількох різних фільмів). Після демонстрації кожної “нарізки” відбувається коротке обговорення, розстановка смислових, емоційних акцентів. Потому - дискусія та узагальнення результатів.

Прийом "нарізки” як ілюстративний матеріал також можна застосовувати в інших форматах медіаклубу для повторного перегляду епізодів, які вважаються доказами, або є підставою для додаткового аналізу, або ж заохочують до дискусії тощо.

Результати впровадження методики "Медіаклуб: розвиток патріотизму молоді". Впровадження методики “Медіаклуб: розвиток патріотизму молоді" відбувалося в рамках проведення практично орієнтованого навчально-методичного семінару для шкільних психологів м. Слов' янська та Слов'янського району Донецької області (19-21 грудня 2017 р.). Упровадження передбачало: вступне слово про актуальність патріотичного виховання молоді (бесіда з учасниками і міні-лекція на тему видів патріотизму); ознайомлення з методикою проведення медіаклубу; безпосереднє проведення медіаклубу з участю шкільних психологів: перегляд художньої стрічки патріотичного контенту “Далекий постріл” режисера В. Шалиги (2005, Україна), аналіз та обговорення в традиційному форматі медіаклубу. Також учасники ознайомилися з іншими форматами проведення медіаклубу: “рольовим”, “інтерпретаційним” підходами, “стоп-кадром” (перший варіант). Крім того, проводилося спостереження за висловлюваннями, поведінковою реакцією учасників медіаклубу, а наприкінці коротке опитування, розроблене на основі методики оцінювання тренінгів (Кирпатрик, 2008).

Результати опитування учасників тренінгу (у кількості 20 осіб) показали, що: емоиійне задоволення від проведення методики "Медіаклуб" отримала більшість (понад 90\%) присутніх; корисною для себе визнали участь у тренінгу близько 90\% учасників; готовність упроваджувати методику у свою практику виявило бажання майже $60 \%$ практичних психологів. Спираючись на отримані дані, можна зробити попередній висновок про те, що представлена методика "Медіаклуб" як один із засобів розвитку патріотизму молоді може розширити інструментальні можливості психологів і медіапедагогів.

\section{Висновки}

1. Розвиток патріотизму молоді, формування ii переконань нині підпадають під стихійний вплив інформаційної (медіа- і кібер-) соціалізації. Тому важливою якістю патріота цифрової доби є розвинена інформаційна медіаграмотність особистості, самостійне, критичне мислення передусім. 
2. Патріотизм молоді і їі медіаграмотність можна розвивати за допомогою методики медіаклубу, суть якої полягає в актуалізації впливу медіаконтенту на емоційну сферу людини; у систематичному аналітичному опрацюванні сприйнятого; у спільному обговоренні фільму, яке стимулює усвідомлення учасниками групової роботи патріотичних цінностей і смислів.

3. Модифікована, оновлена методика збагачує і поглиблює програму розвитку патріотизму, сприяючи розширенню психологічних, інструментальних можливостей для всебічного аналізу патріотичного медіаконтенту, що й робить ії ефективною в досягненні поставленої мети i привабливою для педагогів у роботі з молоддю.

\section{Список використаних джерел}

Ващенко, Г. (1954). Виховання любові до Батьківщини (націоналізм і інтернаціоналізм). Лондон: Видання КК СУМ у В. Британії.

Голубєва, О. Є., Мироненко, Г. В., \& Стерденко, С. М. (2014). “Медіаклуб”. Позашкільні медіаосвітні заняття. Соиіальний педагог, № 12 (96), 44-49.

Донцов, Д. (1936). Патріотизм (с. 48-63). Львів.

Заклинський, Б. (2015). Що треба знати кожному украӥнцеві? Київ: Богуслав-книга.

Кирпатрик, Д. Л., \& Кирпатрик, Дж. Д. (2008). Четыре ступеньки к успешному тренингу. Москва: Эйч Ар Медиа.

Сухомлинский, В. А. (1990). Как воспитать настоящего человека. Москва: Педагогика.

Стасюк, О. Й. (2008). Коссак Зенон. В. А. Смолій (голова) та ін. Енциклопедія історії України (Т. 5: Кон - Кю). Київ: Наукова думка. Взято 3 http://www.history.org.ua/?termin=Kossak_Z

Стасюк, О. Й. (2009). Ленкавський Степан В. А. Смолій (голова) та ін. Енииклопедія історії Украӥни (Т. 6: Ла - Мi). Київ: Наукова думка. Взято 3 http://www.history.org.ua/?termin=Lenkavsky $\mathrm{S}$

Трусь, А. А. (2011). Кинотренинг: технология и методика видеообсуждения. Санкт-Петербург: Речь.

Ушинський, К. Д. (1983). Вибрані педагогічні твори: У 2 m. Київ: Радянська школа.

Череповська, Н. I. (2017). Медіаосвітні ресурси розвитку патріотизму $i$ критичного мислення молоді. Кропивницький: Імекс-ЛТД.

Штомпка, П. (2007). Визуальная соииология. Москва: Логос, 2007.

\section{References}

Vaschenko, H. (1954). Vykhovannia lubovi do Batkivshchyny (natsionalizm $i$ internatsionalizm). London: Vydannia KK SUM u V. Brytanii. (in Ukrainian)

Golubeva, O. Ye., Myronenko, H. V., \& Sterdenko, S. M. (2014). "Mediaklub". Pozashkilni mediaosvitni zaniattia. Sotsialnyi pedahoh, 12 (96), 44-49. (in Ukrainian)

Dontsov, D. (1936). Patriotyzm. Lviv. (in Ukrainian) 
Zaklynskyi, B. (2015). Shcho treba znaty kozhnomu ukraintsevi? Kyiv: Bohuslav-knyha Publ. (in Ukrainian)

Kyrpatryk, D. L., \& Kyrpatryk, J. (2008). Chetyre stupenki $k$ uspeshnomu treningu. Moscow: Egch Ar Media. (in Russian)

Sukhomlinskiy, V. A. (1990). Kak vospitat nastoyashchego cheloveka. Moscow: Pedagogika. (in Russian)

Stasyuk, O. Y. (2008). Kossak Zenon. In A. Smolii (chapter) et al, Entsyklopediia istorii Ukrainy (Tom 5: Kon - Kiu). Kyiv: Naukova dumka. Retrieved from http://www.history.org.ua/?termin=Kossak_Z (in Ukrainian)

Stasyuk, O. Y. (2009). Lenkavskyy Stepan. In A. Smolii (chapter) et al, Entsyklopediia istorii Ukrainy (Tom 6: La - Mi). Kyiv: Naukova dumka. Retrieved from http://www.history.org.ua/?termin=Lenkavsky_S (in Ukrainian)

Trus, A. A. (2011). Kinotrening: tekhnologiya i metodika videoobsuzhdeniya. St. Petsrsburg: Rech Publ. (in Russian) Ukrainian).

Ushynskyi, K. D. (1983). Vybrani twory: in 2 vol. Kyiv: Radianska shkola. (in

Cherepovska, N. I. (2017). Mediaosvitni resursy rozvytku patriotyzmu $i$ krytychnoho myslennia molodi. Kropyvnytskyi: Imeks-LTD. (in Ukrainian)

Shtompka, P. (2007). Vizualnaya sotsiologiya. Moscow: Logos Publ. (in Russian)

\section{Nataliya I. Cherepovska. Development of youth patriotism by psychological means of the media club method}

The article deals with patriotism as a dynamic quality of an individual, which is determined by external factors and in particular by the specific features of a concrete historical period of the society development. The author determines new cognitive instrumental qualities of a patriot in the information society. Those qualities are media literacy and critical thinking of individuals, which is their immunity against any destructive information influence and a guarantee of the integrity of their national identity in conditions of the information warfare. The author considers the development of youth patriotism and new patriotic qualities of an individual by means of the mediapsychological resources and the media club method in particular. It is suggested to enhance the potential of this method by changing its procedure. The author compliments the existing traditional and role formats of holding amedia club meeting with a modified "interpretative" approach of visual sociology, which envisages various approaches to the interpretation of what has been perceived. In addition, an "identifying" version of the media club has been developed. Its participants identify themselves with a film hero and then reflect on their own emotions and feelings, and analyze the thoughts caused by this "transformation". The freeze frame format of the media club, i. e. stop of a moving image, allows for a more detailed analysis of the previous fragment or the key scene of the film. The "illustrative" format of the media club involves the use of "cuts" from different films illustrating the stories with the same theme. This format is suitable for mastering a certain theme and holding a discussion.

Key words: patriotism of an individual, new patriotic instrumental qualities, media-psychological means, media club method, new formats of the media club. 